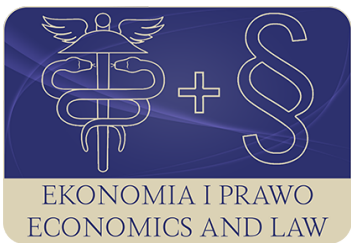

EKONOMIA I PRAWO. ECONOMICS AND LAW

Volume 15, Issue 3, September 2016

p-ISSN 1898-2255, e-ISSN 2392-1625

www.economicsandlaw.pl

ORIGINAL ARTICLE

received 20.10.2015; revised 20.06.2016; accepted 30.09.2016

Citation: Kisiel, S. (2016). The European Public Prosecutor's Office - the fiasco of the European Union financial security vision? Ekonomia i Prawo. Ecomomics and Law, 15(3): 347-356.

doi:10.12775/EiP.2016.023.

\title{
The European Public Prosecutor's Office - the fiasco of the European Union financial security vision?
}

\begin{abstract}
SZYMON KISIEL
University of Warmia and Mazury, Faculty of Law and Administration, Department of Financial Law, ul. Warszawska 98, 10-702 Olsztyn, Poland
\end{abstract}

曰szykis@yahoo.com

\begin{abstract}
Aim: The article is devoted to the problem of financial abuses and frauds that undermines the public finances of EU and public interest.

Motivation: The problem is not new and it is known for several years. There is no doubt that investments funded by the EU are common. A huge amount of EU money is also a huge temptation and purpose of economic crimes. Over the years, the EU and the Member States already took some action to prevent from embezzlement of the EU budget. Until now, the main institution that coordinated the fight against these phenomena was the European Commission and its structure, especially the European Anti-Fraud Office. Fighting against economic crimes violating the interests of the EU is difficult for the procedural reasons. European investigators have no prosecuting power. Investigative role is limited to gathering evidence and transferring it to the national prosecuting authorities. After that European investigators lose the control over conducted case. The Treaty

on the functioning of the European Union gives us another tool to fight the frauds. It seems that the solution is to establish the European Public Prosecutor Office (EPPO) with full procedural rights to prosecute violators. That's why the general thesis is that EPPO should be established as soon as it is possible to help prevent EU citizens money in more effective way than it is today. However this could be a contribution for the next article concerning the economic analysis of the law and the impact of new regulations on security funds entrusted to the EU.

Results: The idea of establishing an EPPO has almost 10 years and was initiated in the connection with the latest financial crisis. Unfortunately, despite declarations and attempts to start it in January 2015 it is still not known if and when it will actually
\end{abstract}


work. The article also takes the issue of commitment and various visions of the Member

States of achieving the EU budget safety and other problems on this ground.

Keywords: fraud; European public prosecutor; EPPO; crime policy; EU budget

JEL: K14; K19; K33

\section{Introduction}

Omnipresence of investment projects financed from the Union budget is indisputable. The funds accumulated in the common budget go first to the European Union regions that are lag behind the Union standards economically. Huge amounts of the Union funds represent, however, the immense temptation and target for criminal activities. Over the years, the Union and its Member States have undertaken various measures aiming at preventing the phenomena causing harm to the interests of the Union budget. All irregularities and cases of abuse should be qualified as threatening the budget. Embezzlement and misuse of the Union funds harms all the Union residents, in particular during the times of economic crisis and more stringent budget discipline in the Member States and the European Union. Hence, there is need for efficient detection of the offenders and bringing them to the bodies of the judiciary. The goal seems logical because while the European Union creates and administers something resembling in form the federal budget then the tool protecting effectively that budget within the area of the entire federation of twenty-eight Member States is necessary. The European Commission is the basic Union institution that conducts and coordinates the combat against those phenomena. The European Anti-Fraud Office (OLAF) $)^{1}$ functions within the framework of its structure. In practical terms, however, the Member States are left alone in their combat against economic crime violating the interests of the Union because the role of OLAF investigators is limited to gathering the evidence material and passing it to the national investigation agencies. The perspective that was opened by the Treaty on the functioning of the European Union (2012), i.e. the possibility of establishing a new body of the Union in the form of the European Public Prosecutor's Office is to be a step streamlining the combat against pathologies threatening the financial security of the EU and its budget.

\section{The current state of knowledge}

\subsection{The European Anti-Fraud Office}

The OLAF was established by the Commission Decision of 28 April 1999. This means that it has been in operation for more than 16 years during which it has detected and prevented all types of offences against the European Union budget.

\footnotetext{
${ }^{1}$ fr. L'office europeen de lute antifraud.
} 
Structurally, the OLAF is a part of the European Commission, although functionally it is independent from it. Granting high autonomy to the OLAF was necessary as detecting corruption offences within the framework of the socalled internal investigations conducted among the Union officers, meaning also the Commission officers, is one of the OLAF competences. OLAF, however, is not the first institution of that type. The $\mathrm{UCLAF}^{2}$ was its predecessor. The Community combat against corruption and abuse goes back to the early 1980's. Initially, the UCLAF functioned as the informal group, the so-called 'flying squad', which could be interpreted as the 'mobile group of investigation officers' (Stefanou et al., 2011, pp. 1-15). They were to conduct random at site inspections and thanks to that detect possible irregularities and cases of abuse. Unfortunately, the Member States were sceptical about the activities of the UCLAF officers, which definitely hindered their effective work. Lack of a legal base for functioning of a group of investigation officers forced taking coordinated actions by the European Commission. The UCLAF formally started its activities in 1988. During a few years, the scope of competences of the UCLAF officers was expanded and in 1995, based on the initiative by the European Parliament, a significant reform of that institution was implemented. The reform was based on 3 changes. The UCLAF employees were granted the right to conduct independent and complete investigations. The UCLAF gained some hundreds of new employees, which was a consequence of expanding the area of its activities. The new UCLAF tasks included proceedings in the area of agriculture and the area of customs and tax abuse, very important to the Community budget. The Treaty of Amsterdam (OJ C340) and two Regulations, 2988/95 (OJ L312/1) and 2185/96 (OJ L292/2), were the base for the implemented reorganisation. Further, the participation of the UCLAF in court proceedings and drafting the acts of indictment was expanded. The policy of coordination of activities and information exchange (Kisiel, 2014, pp. 146-147) between the Member States was also implemented. During ca. 10 years, the competences of the UCLAF as well as the areas of activities expanded significantly. However, based on the Decision by the European Commission of 28 April 1999, the activities of the UCLAF ended and its tasks were taken over by the OLAF. Problems with corruption among the Community officers were among the reasons for disbanding the UCLAF. Ultimately, the OLAF was to become an independent, autonomous organisational unit included in the structure of the European Commission. The Decision 352/99 by the Commission establishing the OLAF and Regulations 1073/99 (OJ L136/1) and 1074/99 (OJ L 136/8) have defined the scope of activities of OLAF as 'any actions related to protection of the Community interests against irregularities that may lead to initiating administrative or penal proceedings'. Currently the OLAF operates at two poles of the European Union budget. On the one hand, it takes care of correctness of obtaining receivables to the benefit of the budget and on the other hand, it protects the expenditures. The current reports from the OLAF activities indicate increasing

2 fr. Unité de Coordination de La Lutte Anti-Fraude. 
effectiveness of its activities. As the result of reorganisation of 2012, more focus was placed on the number of completed proceedings than on the number of new investigations initiated. The outcomes of the OLAF activities are represented by reporting for recovery to the benefit of the EU budget of the amount exceeding 900 million EUR during the last 5 years. It should be remembered, however, that the OLAF is not the entity responsible for taking specific actions aiming at recovery of the amounts lost (Kisiel, 2014, pp. 147-153). At this point, the year budget of the OLAF amounting a little over 57 million EUR should be mentioned. The number of cases reported to the OLAF increases from year to year. In 2010, there were just 975 cases reported and that number increased to 1417 in 2014. The important thing is that the number of denunciations lodged by private entities also increases ${ }^{3}$, which might mean the increasing confidence in the OLAF and its activities. Almost a half of the reports filed concerns abuse of the Union funds, i.e. the structural funds and the funds for agriculture. Significant shortening of the time of investigations conducted by the OLAF investigators should also be interpreted as a success. In 2010, the officers needed the average of 27.2 months for analysing a specific case and possible transfer of materials to the prosecution agencies in the Member States while in 2014 that time was shortened to 21 months. The OLAF results gradually improve but they are still far from ideal. As indicated by the referenced data, the effectiveness of activities undertaken by the OLAF increases and leads to increase in the number of acts of indictment by the national agencies against those committing abuse of different types. Different penal qualification of the offences and as a consequence the possibility of presenting the act of indictment to the offender also is a problem. Punishability of the offence depends on the national penal Act and thus the material gathered by the OLAF is subject to interpretation by the bodies of prosecution of each Member State. This does not have to end in initiating the proceedings. Out of 12 cases passed to the Polish prosecution bodies $^{4} 3$ ended in refusal of initiating or dismissing the proceedings while in 9 cases the offender was accused. The solution could be offered by full harmonisation of the penal provisions at the level of all Member States so that the same offence is interpreted in the same way by public prosecutor's offices in different Member States. The effective activity and improving results of the OLAF result in doubts concerning the sense of establishing a new agency that the European Public Prosecutor's Office would be. Although the legal bases and justified need for establishing the European Public Prosecutor's Office already exist, its actual establishment continues to be uncertain. High diversity in the approach of the Member States to the offences against the common budget is a problem of the Union. Many offenders of abuse are not prosecuted at all by the domestic bodies. Impunity and use of legal gaps harms not only the financial domain of the Union but also the level of confidence and appreciation of the citizens

${ }^{3}$ In 2010 , cases referred by the private entities represented ca. $60 \%$ of the total volume of cases reported to reach ca. 68\% currently (European Commission, 2015b).

${ }^{4}$ During the period from 1 January 2007 through 31 December 2014. 
concerning the institutions and bodies of the European federation. The criminal statistics of the individual countries also show large stratification. The European Public Prosecutor's Office is presented as the solution to that problem.

The idea of establishing the European Public Prosecutor's Office is more than 15 years old. It was initiated already in 1997 but as a consequence of imperfections of the initial concepts and strong critique during the public consultations it was frozen for ca. 10 years. It revived as a consequence of signing the Treaty of Lisbon (OJ C306/1), although the clear signal for commencement of more serious works on the formula of the Office was given in 2012 only by the President of the European Commission Jose Manuel Barroso. It was intended as the message that the European Commission approaches protection of the money of all the EU citizens seriously and with determination. It is worth remaining here the nature of the Union budget, which consists mainly of the $\mathrm{GNI}^{5}$ based own resources (ca. $74 \%$ of the budget), the $0.3 \% \mathrm{VAT}^{6}$ (ca. $9.5 \%$ of the total budget) and the so-called traditional own resources, i.e. customs duties, agricultural charges etc. that provide $10.5 \%$ of the budget. The rest of the budget comes from the minor sources (European Commission, 2015a). This structure causes that the Union citizens finance functioning of the European Union and its initiatives in the indirect way. The plan of establishing the European Public Prosecutor's Office was correlated also with introduction of more restrictive Union policy in the area of preventing financial losses. Implementation of the 'zero tolerance' policy concerning financial abuse applicable to roughly $0.2 \%$ of the year expenditures resulted in decreasing the value of irregularities from 315 million EUR in 2012 to 248 million EUR in 2013. The core of activities of the European Public Prosecutor's Office is to take over the investigation and prosecution in cases in which the financial interests of the Union would be infringed. Currently the national prosecution and judiciary institutions manage the entire process. Given the specific nature of offences of that type, that formula seems ineffective and insufficient. Offences against the Union financial interests are frequently of complicated and crossborder nature, which hinders conducting proceedings by national agencies. Moreover, such proceedings are seen as proceedings of second class of importance and they do not progress as efficiently as the European Commission would like them to progress (European Law Blog, 2013). The change of the investigation type would be a fundamental change. Currently, the investigations conducted by the OLAF are, by definition, administrative proceedings with the option of reclassification by the national agencies. The proceedings that would be conducted by the European Public Prosecutor's Office would be penal proceedings from the very beginning.

${ }^{5}$ Gross National Income - the total domestic and foreign output claimed by residents of a country.

${ }^{6}$ Except Austria (0.225\%), Germany (0.15\%), The Netherlands and Sweden $(0.1 \%$ of the VAT). 


\subsection{The European Public Prosecutor's Office}

Article 86 of the Consolidated versions of the Treaty on European Union and the Treaty on the Functioning of the European Union (OJ C326/01), which provides that in order to combat crimes affecting the financial interests of the Union, the Council, by means of regulation, may establish that Office is the base for considerations on the European Public Prosecutor's Office. The method of voting imposed by Art. 86 is a problem because it provides that the European Public Prosecutor's Office may be established in two ways, both equally complicated and difficult to achieve. The first option that assumes voting at the forum of the EU Council and accomplishment of unanimity requires also support by the European Parliament. This indicates the importance of the subject on which the Council takes the decision because the principle of unanimity is applied in case of issues of key importance to the Union. In case or ordinary organisational and procedural issues, the decisions are taken according to the ordinary or special legislative procedure. Possible lack of unanimity leads to another solution according to which the European Council is included. In that case, on the motion by at least nine Member States the draft regulation on establishment of the European Public Prosecutor's Office can be passed to the session of the European Council. Positive consensus in the European Council results in sending the draft to the EU Council for acceptance. Disregarding the final outcomes of consultations concerning establishment of the European Public Prosecutor's Office, a group of at least nine countries may, based on the existing draft, take the decision on the independent tightening of mutual cooperation for protection of the Union financial interests, which in turn is governed by Art. 329 of the Treaty and Art. 20 of the Treaty on European Union. Such a design, however, raises more doubts instead of dispelling them. Because, what would be the interest of the countries in establishing a group with tighter cooperation while the remaining 19 Member States would be excluded? Subjecting to additional rigors will result in increasing the percentage of abuse cases. That in turn will cause the need for recovering the amounts lost and that, indifferent of the member state is at a very low level. The Union budget, however, accepts no vacuum and the amount defined earlier must be reimbursed to it. We should return here to one of the fundamental principles governing the Union, i.e. the principle of solidarity. The idea of the European Public Prosecutor's Office undoubtedly has some values on condition that it is supported collectively. It is worth quoting Art. 86 in the part concerning the foundation on which the European Public Prosecutor's Office should be established, i.e. '(the Council) may establish a European Public Prosecutor's Office from Eurojust'. This means that the European Public Prosecutor's Office will not be an entirely new body. It will use the potential and experience of the agency the goal of which is to coordinate and increase the effectiveness of the national investigation agencies. Eurojust focuses on combating serious organised crime extending beyond the borders of a single Member State. Employing national prosecutors, judges and repre- 
sentatives of the Police forces it offers the ideal base for establishing a specialised agency that the European Public Prosecutor's Office is to be.

The perspective of establishing the European Public Prosecutor's Office does not mean automatic dissolution of the OLAF although its role will have to be amended. The assumption is that the OLAF should retain the cases that do not satisfy the criteria of cases to be conducted by the European Public Prosecutor's Office, i.e. the administrative proceedings. The clear division of the nature of cases within the responsibility of those two agencies will exclude doubling the investigations at the EU level (European Law Blog, 2013). According to the draft regulation on the European Public Prosecutor's Office, all the Member States, their institutions, agencies, offices, etc. will be obligated to notify the European Public Prosecutor's Office about the possibility of an offence being committed that is within the competences of the European Public Prosecutor's Office immediately. As a consequence of such a notice, the European Public Prosecutor's Office, also without undue delay, will take the decision whether it would initiate its own investigation. In the situation the European Public Prosecutor's Office decides to initiate its investigation, the national entities of the Member State are excluded from the case.

The investigations conducted by the European Public Prosecutor's Office will be based on the national principles applicable to investigations to avoid excessive complication of the progress of proceedings. Part 1, Section 2 of the draft regulation lists the superior principles based on which the European investigation is to be conducted. The list starts with the principles of proportionality of actions taken and legality going down to the rights of the suspect such as the right of being informed about the steps taken, right to translation, right to professional legal counsel, right of gathering evidence and the right of access to the materials gathered during the investigation. The Regulation will implement the principles absolutely necessary for efficient and effective conduct of the investigation and formulation of the act of indictment.

The second part of the proposed Regulation concerns the stage of investigation itself and its details such as interrogation of witnesses or conditions for applying detention.

The third and last part of that Regulation is devoted to the stage of presentation of charges and rendering the judgment by the competent court. It defines, among others, the principles for selecting the court competent for the case in the Member State. It was assumed that jurisdiction by a court of the Member State in the territory of which the majority of proceedings are conducted. Further, the origin of the offender and the country in which the majority of evidence has been secured are decisive. If, however, none of the above criteria are sufficient than the court with the jurisdiction over the domicile of the European Public Prosecutor's Office will be the court competent for the case. The rights of the accused, however, have been secured and the possibility of lodging the appeal against the choice made by the Office to the European Court of Justice has been provided. 
The structure of the European Public Prosecutor's Office will be scattered and decentralised. This is the consequence of, among others, the differences in organisation of the judiciary in the different Member States and bringing the decentralised structures of the European Public Prosecutor's Office should facilitate cooperation. The Collegium of Ten, i.e. the European Public Prosecutor, four deputies and five of the representatives of the Public Prosecutor's Offices of the Member States will head the entire organisation. The candidate for the position of the European Public Prosecutor will be appointed from the list drafted by the European Commission. The decision is to be taken by the Council by the qualified majority of votes on consent by the European Parliament. The function is to be held for the term of 6 years and limited to just a single term in office (EU4Journalists, 2015). The main task of the European Public Prosecutor and deputies will be to coordinate the activities, assure integration and efficient cooperation at both the Union and the national level. Branches positioned in the Member States will conduct the individual investigations. This means that the Member State that subjects itself to the rigors of the European Public Prosecutor's Office will have to appoint at least one prosecutor, which will be conducting investigations on behalf of the European Public Prosecutor's Office. The Member States will determine the specific number of such representatives.

\section{The methodology of research}

The following research methods were used in this article: historical-legal method, legal dogmatic method, statistical analysis.

\section{The research process}

The research process was mainly based on historical, existing and forthcoming legislation acts. There has also been a traditional and virtual press review. The author also used few thematic publications.

\section{The results of research}

As a result of the research some conclusions were made but none of them is certain due to legislative EU process and political needs.

\section{Conclusion}

Unfortunately, despite numerous declarations and attempts at starting up the operations of the European Public Prosecutor's Office in January 2015, it still remains a plan only. The practitioners, and in particular prosecutors from the European countries are particularly sceptical. In the discussions on establishment of the European Public Prosecutor's Office are frequently dominated 
by the opinion that the difficulties involved in establishment of it and conflicts between countries may exceed the potential benefits. In March 2013, France and Germany lobbied very strongly for establishment of the European Public Prosecutor's Office while Denmark, the United Kingdom and Ireland were not interested in cooperation in that area at all (European Commission, 2015a). Despite some doubts the EPPO should be established as soon as it is possible. For the good of the whole community of EU people. Good and strong EPPO can probably keep our common money safe. Given the significant difficulties in establishing the European Public Prosecutor's Office, the European Commission is also undertaking parallel activities of reforming the system of cooperation in criminal cases (Eurojust) (COM/2013/0256) and further improvement of the OLAF (COM/2013/533).

Concluding the considerations on the European Public Prosecutor's Office, the need for establishing it should be highlighted first. Improvement in the Union funds spending effectiveness and minimising the losses involved should become one of the priorities. Any pathologies result in losses to the Union budget that is contributed to meticulously by all the Union citizens. However, the need is one thing while the European pragmatics is the other. The quick start of EPPO may bring considerable profits to EU budget. Nowadays around E3,7 billion, depending on the year, are taken under financial corrections because of irregularities reported as fraudulent (in expenditures and revenues side of the EU budget). At the same time the amount of the recoveries is only E680 million per year. This means that not more than $20 \%$ of misappropriated funds are successfully recovered. This is the field that EPPO can definitely improve by its prosecuting power. The European Union knows numerous cases of the right ideas that, because of the divergent interests of the Member States have never come into life. We should only hope that the process of establishing the European Public Prosecutor's Office is advanced so far that there is no return and the only thing that remains to be determined is the formula according to which it will start operating.

\section{References}

Communication from the Commission to the European Parliament, the Council, the European Economic and Social Committee and the Committee of the Regions Improving OLAF's governance and reinforcing procedural safeguards in investigations: A step-by-step approach to accompany the establishment of the European Public Prosecutor's Office (COM/2013/533).

Consolidated versions of the Treaty on European Union and the Treaty on the Functioning of the European Union from 2012 (OJ C326/01).

Council Regulation (EC, Euratom) No 2988/95 of 18 December 1995 on the protection of the European Communities financial interests (OJ L312/1).

Council Regulation (Euratom) No 1074/99 of 25 May 1999 concerning investigations conducted by the European Anti-fraud Office (OLAF) (OJ L 136/8). 
Council Regulation (Euratom, EC) No 2185/96 of 11 November 1996 concerning on-the-spot checks and inspections carried out by the Commission in order to protect the European Communities' financial interests against fraud and other irregularities (OJ L292/2).

EU4Journalists. (2015). Retrieved 27.09.2015 from http://www.eu4journalists.com.

European Commission. (2015a). Retrieved 15.09.015 from http://ec.europa.eu.

European Commission. (2015b). The OLAF report 2014. Retrieved 20.09.2015 from http://ec.europa.eu.

European Law Blog (2013). Retrieved 13.09.2015 from http://europeanlawblog.eu.

Kisiel, S. (2014). Nieprawidtowe wykorzystanie środków unijnych. Aspekty prawno-kryminologiczne. Olsztyn: UWM.

Proposal for a regulation of the European Parliament and of the Council on the European Union Agency for Criminal Justice Cooperation (Eurojust) (COM/2013/0256).

Regulation (EC) No 1073/1999 of the European Parliament and of the Council of 25 May 1999 concerning investigations conducted by the European Anti-Fraud Office (OLAF) (OJ L136/1).

Stefanou, C., White, S., \& Xanthaki, H. (2011). OLAF at the Crossroads: Action against EU fraud. Studies in international \& comparative law. Oxford and Portland/Oregon: Hart Publishing.

Treaty of Amsterdam of 10 November 1997 (OJ C340).

Treaty of Lisbon amending the Treaty on European Union and the Treaty establishing the European Community, signed at Lisbon, 13 December 2007 (OJ C306/1).

\section{Acknowledgements}

Author contributions: author have given approval to the final version of the article. 